\title{
THE RATE OF FEEDING BY MYTILUS IN DIFFERENT KINDS OF SUSPENSION
}

\author{
By C. Barker J $\phi$ rgensen \\ From the Plymouth Laboratory, and the Laboratory of Zoophysiology, \\ University of Copenhagen
}

(Text-figs. I-3)

\section{INTRODUCTION}

Most lamellibranchs obtain their food from the particulate matter, microorganisms or fine dispersed detritus, suspended in the surrounding water. The lamellibranchs transport water through the gills which serve as filters and retain the suspended particles. By means of cilia the material held back on the gill surfaces may be transported towards the mouth opening and ingested. In the quantitative feeding biology of this type of lamellibranch it is therefore of interest to know the water transportation capacity of the gills and also their efficiency in retaining particles from the filtered water. The amount of water transported through the gills has been measured by several investigators. Both direct and indirect methods have been employed. In the direct methods, for example that by Loosanoff \& Engle (1947) on oysters, the water leaving the experimental animals through the exhalant siphon was separated from the surrounding water, collected, and measured. In the most frequently used indirect methods, the water transport was estimated from the rate of disappearance of particles from the surrounding water. However, the indirect method will measure the total amount of water transported only if the particles present in that water are all retained by the gills. If only a certain percentage is retained the value obtained will be lower, representing a certain volume cleared from particles. These particles may or may not be of any value as food and may or may not be ingested. The volume of water cleared from particles represents the potential feeding rate of the animal in question, or, more simply, the feeding rate.

If the size of food particles in the water is of importance for their retention by the gills, the indirect method offers information of greater importance concerning the feeding biology of the lamellibranchs than does the direct method. It is therefore of interest to investigate the efficiency of the gills in keeping back particles from the inhaled water. Only very few quantitative experiments dealing with this problem are available: they were performed on Ostrea and Mytilus. Galtsoff (1928) found that the oyster keeps back only a small fraction of Bacterium coli added to the water; $70-90 \%$ escaped the gill filter and could be recovered in the exhaled water. Loosanoff \& Engle (1947), 
likewise working on oysters (Ostrea virginica), determined the percentage retention of cells of Chlorella, Nitzschia, and Euglena in the gills. For Chlorella cells (about $5 \mu$ in diameter) the value obtained varied from $\circ$ to $92 \%$. Apparently the gills function more efficiently at smaller concentrations than at larger ones. Nitzschia and even Euglena viridis (about $60 \mu$ ) were also found to pass through the gills, only $15-80 \%$ of Euglena cells being retained. In these experiments no correlation was found between the number of cells present in the water and the percentage removed. ZoBell \& Landon (I937) stated that the gills of the California mussel retain bacteria very efficiently, although these authors do not mention directly the degree of retention. Therefore it seems possible that the pore sizes of the gills of Mytilus are smaller than those of oysters. However, the question arises whether the efficiency of the gills in retaining particles is always the same in one and the same animal. This is probably not so. Apart from possible changes in pore sizes of the gill filters arising from changed contraction of muscle fibres in the gill filaments, the animals seem to have other means of changing the efficiency of the gills. MacGinitie (I94I) observed the gills through glass windows in the shells and he found that lamellibranchs, when quite undisturbed, can produce a layer of mucus covering the gill surfaces. This sheet of mucus most probably retains particulate matter present in the water down to very small particles, in any case far below bacterial sizes. The mucus including the particles is transported towards the mouth opening by means of the cilia and ingested. MacGinitie holds the view that lamellibranchs are feeding, i.e. ingesting the collected food material, only when they are producing the sheet of mucus. Furthermore, he states that they will only secrete the mucus layer when they are quite undisturbed and have been so for some time, and only if they accept particulate matter in the water as food. According to this view, perhaps all earlier experiments on feeding rates of lamellibranchs are open to criticism in the sense that under the experimental conditions the animals have not really been feeding. Against this assumption it may be said that in many of the experiments mentioned an uptake of particles in the alimentary tract has actually been demonstrated. The possibility thus exists that lamellibranchs may feed both with and without formation of a mucus layer. It was therefore thought worth while to investigate further the feeding behaviour of the lamellibranchs under conditions as natural as possible, using suspensions of both 'natural' (micro-organisms) and 'artificial' (graphite) particles as medium.

Since the $\mathrm{NH}_{2}-\mathrm{N}$ content of an animal is a more satisfactory measure of the amount of living tissue than are length or weight, the feeding rate has been expressed per $\mathrm{NH}_{2}-\mathrm{N}$ unit in the experimental animals.

The experimental part of the present investigation has been performed at the Plymouth Laboratory. I wish to express my sincere thanks to the Director, 
Mr F. S. Russell, for the great interest he has taken in the work and for providing all the necessary working facilities. My most cordial thanks are due to Dr Mary Parke, who prepared the gallons of culture used. I am greatly indebted to Dr W. R. G. Atkins who suggested the use of the colloidal graphite, and to E. G. Acheson Ltd., London, who placed the graphite at my disposal. The work has been made possible through a grant from the RaskØrsted Foundation.

\section{TeChNIQUe}

Since small mussels seem to be less sensitive to handling and to changes in environment than larger individuals, the experiments were performed on small specimens of Mytilus edulis (L.) varying in length from about I to $5 \mathrm{~cm}$. The mussels were collected from the piles of the old Plymouth pier. They were found to be most active when they remained in the naturally occurring clusters. To make sure that mussels of approximately the same size were used in the single experiments, the average size of the animals in the individual cluster was given preference, and animals of extreme sizes were removed together with those completely covered by their neighbours. Moreover, only those animals were chosen which were oriented so that their siphons were freely exposed to the surrounding medium. The resulting clusters contained between fifteen and fifty individuals, depending on the size of the individuals. The experimental vessels were of such shape and size that the mussels were able to keep the total water volume well mixed. Prior to the experiments, the mussels were adapted for several days to the running water from the circulation system of the laboratory. During that period the animals arranged themselves in an almost globular mass and moreover attached themselves to the bottom of the vessel by means of byssus threads. At the start of an experiment the water was replaced by the desired suspension, either freshly neutralized alga culture in vigorous growth diluted with tank water, or suspensions of graphite. A dilution of one part of alga culture with two to four parts of tank water was mostly used. Between subsequent experiments the animals were kept in running water. The temperature during the experiments varied between 17 and $20^{\circ} \mathrm{C}$. The rate of feeding was computed from the formula

$$
P_{t}=P_{0} \exp \left[-\frac{m}{M} t\right],
$$

where $M$ is the quantity of water used for the experiment, and $m$ the quantity 'cleared' from particles per unit time, while $P_{t}$ and $P_{0}$ are the concentrations of the suspended material at the time $t$ and o, respectively (Jørgensen, I943).

As suspended material Nitzschia closterium forma minutissima, and flagellates ' $\mathrm{B}$ ', ' $\mathrm{I}$ ' and ' $\mathrm{J}$ ', which were kept in permanent culture in the Plymouth Laboratory, were employed. The first two of these have now been described by Parke (1949) and named Dicrateria inornata and Isochrysis galbana 
respectively. Colloidal graphite was also used, from two different samples, viz. 'Prodag', grade 'C', and 'Aquadag', grade 'S', both supplied by E. G. Acheson Ltd., London. They are here referred to as graphite ' $\mathrm{C}$ ' and graphite ' $S$ '. The concentrations of the suspensions were determined photometrically by means of a portable 'Eel' photometer. $\mathrm{NH}_{2}-\mathrm{N}$ determinations were made according to Parnas' (I938) micro-modification of the Kjeldahl analysis.

\section{RESULTS}

The results obtained on the feeding behaviour of Mytilus differed according to the kind of suspensions used. The experiments with suspensions of graphite, flagellates, and Nitzschia, respectively, will be dealt with separately.

Experiments with graphite suspensions. When suspensions of graphite were used the values of the feeding rates decreased during the experiments. Some typical examples are given for graphite ' $S$ ' in Fig. I, and for graphite ' $C$ ' in Fig. 2. Tables I and II summarize the numerical material obtained in experiments with graphite suspensions. Only the first and last values of feeding rates measured during one single experiment are recorded in the Tables (columns (iii) and (iv)). In column (v) the end value is expressed as a percentage of the value at the start. It is seen that at the time the experiments were concluded the feeding rates were often less than $10 \%$ of the feeding rates at the start. Sometimes, however, the decrease in feeding rate was only slight.

Two different mechanisms may be responsible for a decrease in feeding rate, viz. either a decreasing rate of transport of water through the gills, or a decrease in the percentage of suspended particles retained by the gills. Alternatively, both processes might occur simultaneously. Probably both mechanisms are of importance, as will appear from the following considerations.

During the experiments the general behaviour of the experimental animals was also studied. From observing the positions of the valves, the degree of extension of the siphons, and especially the movements on the surface of the water caused by the water currents produced by the animals, a rather rough measure for changes of the amount of water transported through the animals could be obtained. It was found that when the mussels were transferred from pure sea water to graphite suspensions they sometimes showed decreasing activity in the course of the experiment. This occurred in five out of seventeen experiments. In the twelve other experiments, however, there was no visible change in the activity of the mussels throughout the experimental period. Nevertheless, even under such circumtances the feeding rates were often much lower at the end of the experiment than at the start. Figs. I and 2 show two such examples; the same may be seen also from Tables I and II, column (vi), where notes have been made on such activity of the mussels as could be directly observed. In these mussels the percentage of particles retained by the gills decreased during the experiments.

The particles in the graphite suspensions were not all of equal size, as the 


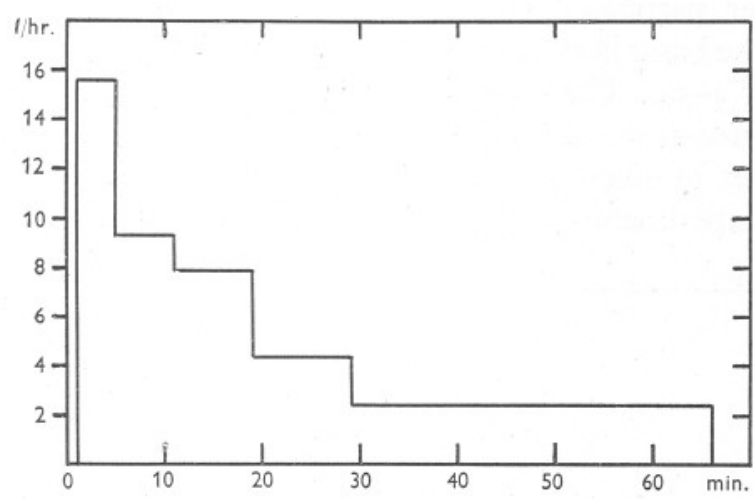

Fig. I. Feeding rates in $1 . / \mathrm{hr}$. of Mytilus edulis in suspensions of graphite ' $\mathrm{S}$ '.

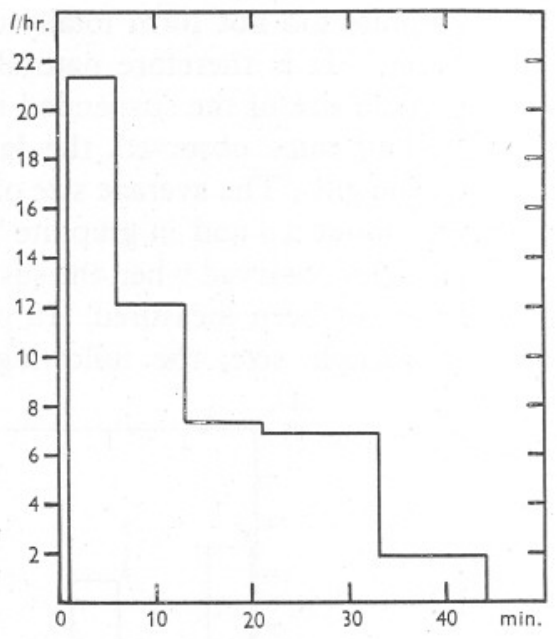

Fig. 2. Feeding rates in 1./hr. of Mytilus edulis in suspensions of graphite ' $\mathrm{C}$ '.

\section{TABle I. EXPeriments with Suspensions of Graphite ' $S$ '}

$c$ means that the activity of the animals remained high and unchanged during the experiment, whereas $d$ indicates that a decreasing activity was observed.

\begin{tabular}{|c|c|c|c|c|c|}
\hline Mytilus & & Feeding ra & te $(1 . / \mathrm{hr})$. & End value & \\
\hline no.) & Date & Initial value & End value & of initial value & \\
\hline (i) & (ii) & (iii) & (iv) & (v) & (vi) \\
\hline II & I7. vi. & $9 \cdot 4$ & 0.9 & IO & 一 \\
\hline I4 & 2I. vi. & $3 \cdot 7$ & $I \cdot 6$ & 43 & $f$ \\
\hline I4 & 2I. vi. & $4 \cdot 2$ & 0.4 & IO & $d$ \\
\hline I4 & 23. vi. & $8 \cdot 4$ & $3 \cdot 6$ & 43 & $c$ \\
\hline I4 & 23. vi. & $9 \cdot 4$ & $4 \cdot 7$ & 50 & $c$ \\
\hline I6 & 30. vi. & $28 \cdot 7$ & I6. 5 & 58 & $c$ \\
\hline I6 & I. vii. & $5 \cdot I$ & 0.9 & I8 & $c$ \\
\hline I6 & I. vii. & $7 \cdot 6$ & $I \cdot 9$ & .25 & $c$ \\
\hline I6 & 3. vii. & $22 \cdot 6$ & I9.0 & 84 & $c$ \\
\hline I6 & 3. vii. & II $\cdot 2$ & I. 7 & I5 & $d$ \\
\hline I6 & 3. vii. & $15 \cdot 6$ & $2 \cdot 7$ & I5 & $c$ \\
\hline I6 & 6. vii. & $6 \cdot 4$ & 0.4 & 6 & $c$ \\
\hline I6 & 8. vii. & $12 \cdot 5$ & $I \cdot O$ & 8 & 一 \\
\hline
\end{tabular}

Table II. Experiments with Suspensions of Graphite 'C'

\begin{tabular}{|c|c|c|c|c|c|}
\hline Mytilus & & Feeding $\mathrm{r}$ & ate (1./hr.) & End value & \\
\hline no.) & Date & Initial value & End value & of initial value & \\
\hline (i) & (ii) & (iii) & (iv) & (v) & (vi) \\
\hline II & I7. vi. & $5 \cdot 8$ & $\mathrm{I} \cdot 8$ & $3 I$ & $d$ \\
\hline II & I8. vi. & I3.I & 2.4 & I8 & - \\
\hline II & I8. vi. & 9.4 & $2 \cdot 2$ & $2 \mathrm{I}$ & - \\
\hline II & I8. vi. & $2 \mathrm{I} \cdot 3$ & I.9 & 9 & $c$ \\
\hline I6 & 3. vii. & $26 \cdot 2$ & 24.5 & 94 & $c$ \\
\hline I6 & 3. vii. & 33.5 & $3 I \cdot 0$ & 93 & $c$ \\
\hline I6 & 7. vii. & 6.5 & 2.5 & 38 & , \\
\hline I6 & 8. vii. & I2. 5 & $I \cdot O$ & 8 & $d$ \\
\hline
\end{tabular}


graphite did not form totally dispersed and quite stable suspensions in sea water. $^{1}$ It is therefore natural to assume that the heterogeneity as regards particle size of the suspended material may be responsible for the decreasing feeding rates observed, the larger particles being more selectively retained by the gills. The average size of the basic particle in graphite ' $S$ ' suspensions was about $2 \mu$ and in graphite 'C' $4-5 \mu$. The sizes of the aggregates of basic particles observed when the suspensions were examined under the microscope have not been measured. In order to investigate more closely the influence of particle size, the following experiments were made. In each of four

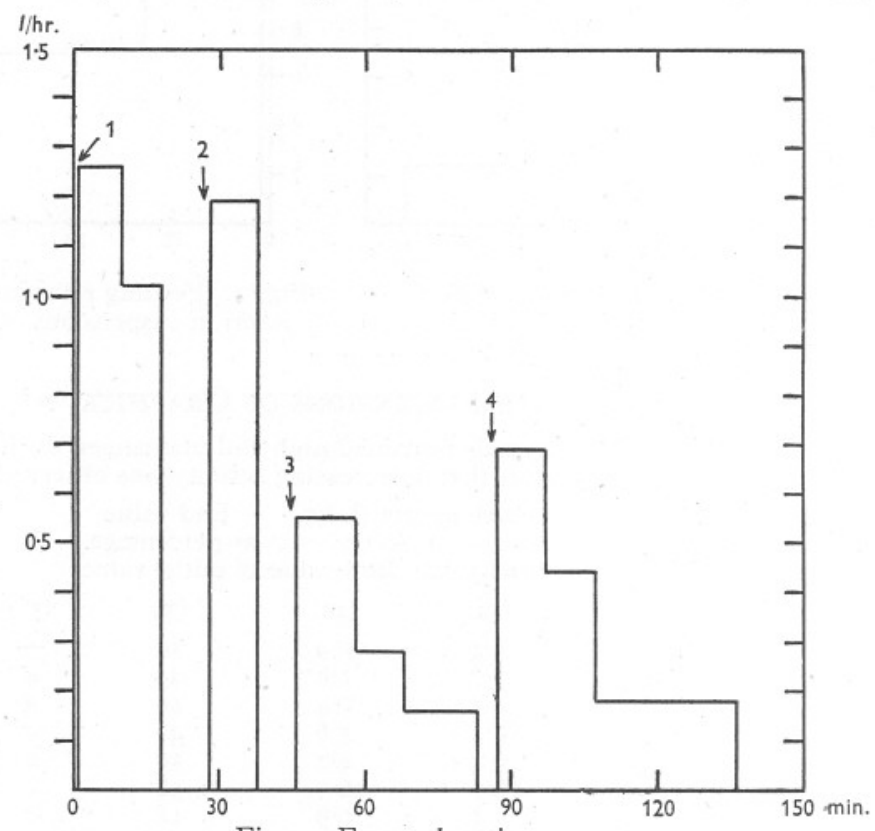

Fig. 3. For explanation, see text.

finger bowls were placed two mussels about $3 \mathrm{~cm}$. in length. At the start of the experiment $250 \mathrm{ml}$. of graphite suspension were added to each of the bowls and the experiments were run until the concentration of the suspensions in each was reduced to about one-third. During this period, two determinations on the feeding rates were made. The second determination was always lower than the first. This is seen in Fig. 3, which represents the average

1 A curve representing measurements of the light absorption (ampèremeter readings) at different dilutions of a standard suspension was used to determine the concentration of the suspensions during the experiments. Strictly speaking, this method is of course not admissible where the ratio between larger and smaller particles changes during an experiment, as most certainly occurred in the graphite experiments. With decreasing average particle size the densities of particles measured from the curve will be lower than the real densities, which means that the amount of water measured as cleared from particles will be too large. In fact, the decreases in feeding rates have been still larger than stated in the tables. This error will, however, not effect the conclusions to be drawn from the experiments. 
of the four experiments. At the end of the period the suspension was decanted and stored for later use, and replaced by fresh graphite suspension taken from the same standard suspension as used previously. This time one determination of the feeding rate was made at the time when the concentration of the suspension was reduced to about one-half. Immediately after, the rest of the suspension was decanted and replaced by the suspension used initially. The feeding rates after the second addition of fresh suspension were always higher than the preceding ones. During the third period of the experiment the animals once more filtered the suspensions in which they had started until the concentration of the suspensions was about one-eighth of the initial value. It is seen that the values of the feeding rates decrease with time, and even at the start are lower than the preceding figures in fresh graphite suspension. Finally, the suspension left from the second period of the experiment was used once more. Immediately after addition of the suspension the feeding rates are relatively high, but they decrease later. This experiment, further, gives strong evidence for the view that under the prevailing experimental conditions Mytilus retained larger particles more efficiently than smaller ones.

Experiments with suspensions of flagellates. Of the three flagellates used in the experiments, Dicrateria inornata (' $\mathrm{B}$ ') is spheroidal, about $3-5.5 \mu$ in diameter; Isochrysis galbana (' $\mathrm{I}$ ') is ellipsoidal, 5-6 $\mu$ long, 3-4 $\mu$ broad and $2 \cdot 5-3 \mu$ thick; whereas flagellate ' $\mathrm{J}$ ' is ovoid, about $6-8 \mu$ long and $3-4 \mu$ broad. The results of the experiments are given in Table III. When using suspensions

TABle III. EXPeriments with Suspensions of DifFerent Flagellates

\begin{tabular}{|c|c|c|c|c|c|}
\hline \multirow{2}{*}{$\begin{array}{l}\text { Mytilus } \\
\text { (specimen } \\
\text { no.) } \\
\text { (i) }\end{array}$} & \multirow[b]{2}{*}{$\begin{array}{l}\text { Date } \\
\text { (ii) }\end{array}$} & \multicolumn{2}{|c|}{ Feeding rate $(1 . / \mathrm{hr})}$. & \multirow{2}{*}{$\begin{array}{l}\text { End value } \\
\text { as percentage } \\
\text { of initial value } \\
\text { (v) }\end{array}$} & \multirow[b]{2}{*}{ (vi) } \\
\hline & & $\begin{array}{c}\text { Initial value } \\
\text { (iii) }\end{array}$ & $\begin{array}{l}\text { End value } \\
\text { (iv) }\end{array}$ & & \\
\hline \multicolumn{6}{|c|}{ Flagellate ' $\mathrm{J}$ ' } \\
\hline 2 & I3. vi. & $I \cdot 0$ & O.II & II & 一 \\
\hline 8 & I3. vi. & 0.21 & 0.44 & 209 & - \\
\hline 9 & I3. vi. & 0.23 & 0.29 & 126 & - \\
\hline II & I9. vi. & $6 \cdot 6^{\circ}$ & 14.5 & 219 & - \\
\hline II & I9. vi. & 29.5 & 29.0 & 98 & - \\
\hline II & I9. vi. & 29.5 & 29.5 & Ioo & - \\
\hline \multicolumn{6}{|c|}{ Isochrysis galbana } \\
\hline I4 & 23. vi. & $3 \cdot 3$ & $5 \cdot 4$ & I63 & - \\
\hline I4 & 23. vi. & $3 \cdot 4$ & 2.8 & 82 & - \\
\hline I6 & 30. vi. & 9.0 & IO. I & II 2 & - \\
\hline I6 & 30. vi.: & $7 \cdot 2$ & $9 \cdot 7$ & I35 & - \\
\hline I6 & 6. vii. & II. 4 & $2 \mathrm{I} \cdot 3$ & I87 & 一 \\
\hline \multicolumn{6}{|c|}{ Dicrateria inornata } \\
\hline 2 & I4. vi. & 0.28 & 0.26 & 93 & 一 \\
\hline 8 & I4. vi. & 0.38 & 0.10 & 26 & 一 \\
\hline 9 & I4. vi. & 0.17 & 0.17 & 100 & - \\
\hline II & I9. vi. & I9. 4 & 3.5 & I8 & - \\
\hline II & I9. vi. & $28 \cdot 0$ & $I \cdot I$ & 4 & $c$ \\
\hline I4 & 23. vi. & $10 \cdot 0$ & $4 \cdot 4$ & 44 & $c$ \\
\hline 16 & 26. vi. & 13.5 & 15.0 & I I I & - \\
\hline
\end{tabular}

JOURN. MAR. BIOL. ASSOC. vol, XXVIII, I 949 
of the two last, the feeding rates measured were usually constant or increasing during the experiment. Only in one experiment out of eleven a pronounced decrease was observed. With Dicrateria, four experiments out of seven showed a pronounced decrease in feeding rates with time. In some of these at least the transport of water through the animals did not change noticeably, as judged from the direct observations of the behaviour of the mussels and the movements of the water. The decreasing feeding rates must therefore be caused by a decreasing retention of flagellates in the gills. As the particle size of the suspension is rather uniform, this factor cannot explain the decreasing rate. It seems that the 'pore' sizes of the gills can be changed so that the gill filter may be more or less permeable to particles of the same size. Furthermore, a comparison of Tables I, II and III shows that when suspensions of flagellates are used the feeding rates obtained are usually much higher than the feeding rates found with graphite suspensions in the later parts of the experiments when the smaller particle sizes most certainly dominate. This holds especially when the flagellate ' $\mathrm{J}$ ' experiments are compared with the graphite experiments. See, for example, the experiments on Mytilus specimen no. II from I7 to I8 June (graphite) and from I9 June (flagellate 'J'). This means that the gills of the mussels may, and normally do, retain flagellates much more effectively than graphite particles even when these two kinds of particles are of about the same size.

Experiments with Nitzschia. The experiments with suspensions of Nitzschia lead to rather uniform results (Table IV). The feeding rates were found to be

\begin{tabular}{|c|c|c|c|c|c|}
\hline \multirow{3}{*}{$\begin{array}{l}\text { Mytilus } \\
\text { (specimen } \\
\text { no.) } \\
\text { (i) }\end{array}$} & \multirow{3}{*}{$\begin{array}{l}\text { Date } \\
\text { (ii) }\end{array}$} & \multicolumn{2}{|c|}{ Feeding rate $(1 . / \mathrm{hr})}$. & \multirow{3}{*}{$\begin{array}{c}\text { End value } \\
\text { as percentage } \\
\text { of initial value } \\
\text { (v) }\end{array}$} & \multirow[b]{3}{*}{ (vi) } \\
\hline & & Initial value & End value & & \\
\hline & & (iii) & (iv) & & \\
\hline II & I8. vi. & $6 \cdot 2$ & II $\cdot 9$ & I92 & - \\
\hline I4 & 2I. vi. & 6.0 & $7 \cdot 8$ & 130 & \\
\hline 16 & 26. vi. & 15.0 & 19.0 & I 27 & \\
\hline I6 & 27. vi. & 9.5 & 13.2 & 125 & \\
\hline I6 & 27. vi. & 13.4 & I 3.7 & 102 & - \\
\hline 16 & 30. vi. & 10.4 & 13.5 & I30 & - \\
\hline I6 & 3०. vi. & 10.4 & I 4.3 & I 37 & - \\
\hline I6 & I. vii. & 28.0 & 29.0 & 103 & \\
\hline I6 & 3. vii. & I2.7 & $2 \mathrm{I} \cdot 6$ & I70 & \\
\hline I6 & 3. vii. & I9. I & $25 \cdot I$ & I3I & \\
\hline I6 & 3. vii. & 27.5 & $28 \cdot 4$ & 103 & - \\
\hline I6 & 5. vii. & 12.0 & 20.3 & 169 & \\
\hline I6 & 5. vii. & $17 \cdot 2$ & 23.9 & I39 & - \\
\hline I6 & 5. vii. & $2 I \cdot 2$ & $20 \cdot 4$ & 96 & \\
\hline I6 & 5. vii. & I9.4 & $\begin{array}{r}9.0 \\
9\end{array}$ & 46 & $d$ \\
\hline I6 & 7. vii. & 8.5 & I0.8 & 127 & \\
\hline I6 & 8. vii. & 5.3 & 10.9 & 206 & \\
\hline
\end{tabular}

constant or, most often, to increase during the experiments. Only in one experiment out of seventeen was there observed a pronounced decrease in the 
rate of feeding, when it was very conspicuous that the water propulsion from the mussels had also diminished towards the end of the experiment. The pronounced tendency to lower feeding rates, which was found at the start of the experiments with Nitzschia as well as in many of the experiments with flagellate ' $\mathrm{J}$ ', is most probably caused by the heavy load of micro-organisms deposited on the gills at the start of the experiments. The suspensions used were comparatively thick, as could be estimated from the large amounts of pseudo-faeces formed by the mussels.

\section{Discussion}

The results from the experiments on the feeding rate of Mytilus in different suspensions seem rather divergent. In graphite suspensions containing particles ranging from about $2 \mu$ and $4-5 \mu$ to much larger ones, the larger particles were most frequently found to be retained more effectively than the smaller ones. Occasionally, however, the feeding rates were found to be high and almost constant during the experiments, thus indicating that the percentage of graphite particles retained by the gills had been high and independent of particle size (e.g., Table II, specimen no. I6, 3 July). In suspensions of flagellates with an average particle size close to the minimum size of particles in suspensions of graphite ' $\mathrm{C}$ ', the percentage of micro-organisms retained by the gills was usually high and remained constant during the experiment, but in some instances it decreased. Once, indeed, the last measured feeding rate was only $4 \%$ of the feeding rate found in the beginning of the experiment (Table III, specimen no. II, I9 June). In the later periods of the graphite experiments, when most of the bigger particles had presumably been removed from the suspension, the feeding rates were often found to be less than 10\% of the feeding rates in suspensions of flagellates. This was observed even when there was no indication of a lower rate of water transport through the experimental animals. It must therefore be concluded that, under certain conditions, the gills of M.edulis retain only a small fraction of particles about $5 \mu$ in diameter, whereas, at other times and under different conditions, particles of the same size are retained much more efficiently. This observation concerning the ability of the gills is in good agreement with the investigations of MacGinitie (I94I) on the feeding behaviour of lamellibranchs referred to on p. 334. If MacGinitie's observations are taken into account the present experiments may be interpreted in the following way. In graphite suspensions Mytilus must be assumed normally not to accept the particles as food. Consequently they will not produce a mucus cover on the gills, and the efficiency with which particles are retained will depend entirely upon the particle size. That the mussels were genuinely disturbed in graphite suspensions could be seen from the fact that in five out of seventeen experiments with graphite decreasing activity during the experiments manifested itself in the general behaviour of the animals. On the other 
hand, presentation of flagellate suspensions to the mussels clearly as a rule had no depressing effect on the formation of the mucus layer. In this event the retention of micro-organisms by the gills must have been approximately complete. It is difficult to imagine how flagellates should be able to penetrate a layer of mucus. In the experiments with Nitzschia it must be assumed, too, that the retention of cells in the gills was almost complete, as the feeding rates found were of the same order of magnitude as in the flagellate experiments. Moreover, only in four experiments out of twenty-nine with suspensions of flagellates or Nitzschia was decreasing activity of the mussels, with respect to the transport of water, observed during the experiments. This also indicates that the mussels tolerated and accepted the suspended material.

From the above considerations it must be assumed that the constant feeding rates found in suspensions of flagellates and Nitzschia probably give the total volume of water transported through the gills. Table $\mathrm{V}$ collates the values of

\begin{tabular}{|c|c|c|c|c|c|c|c|c|}
\hline \multirow{2}{*}{$\begin{array}{c}\text { Mytilus } \\
\text { (specimen } \\
\text { no.) }\end{array}$} & \multirow[b]{2}{*}{ Date } & \multirow{2}{*}{$\begin{array}{c}\text { Average } \\
\text { length } \\
\text { (cm.) }\end{array}$} & \multirow[b]{2}{*}{$\begin{array}{l}\text { No. of } \\
\text { animals }\end{array}$} & \multicolumn{2}{|c|}{$\mathrm{NH}_{2}-\mathrm{N}$ (mg.) } & \multirow[b]{2}{*}{ Suspension } & \multirow{2}{*}{\multicolumn{2}{|c|}{$\begin{array}{l}\text { Feeding rate } \\
\text { in ml. per hr. } \\
\text { per mg. } \mathrm{N}\end{array}$}} \\
\hline & & & & Total & $\begin{array}{c}\text { Average } \\
\text { per animal }\end{array}$ & & & \\
\hline I4 & 2I. vi. & $I \cdot 5$ & 56 & I IO & 2 & Nitzschia & & 63 \\
\hline I4 & 23. vi. & $I \cdot 5$ & 56 & I IO & 2 & Dicrateria & & 94 \\
\hline I4 & 23. vi. & $\mathrm{I} \cdot 5$ & 56 & I IO & 2 & Isochrysis & & $8 \mathrm{I}$ \\
\hline I4 & 23. vi. & $\mathrm{I} \cdot 5$ & 56 & IIO & 2 & Dicrateria & & 86 \\
\hline \multirow[t]{2}{*}{ I4 } & 23. vi. & $\mathrm{I} \cdot 5$ & 56 & IIO & 2 & Dicrateria & & 74 \\
\hline & & & & & & \multicolumn{2}{|c|}{ Average } & 80 \\
\hline I6 & 26. vi. & $2 \cdot 9$ & 25 & 555 & 22 & Nitzschia & & $3 I$ \\
\hline I6 & 27. vi. & $2 \cdot 9$ & 25 & 555 & 22 & Nitzschia & & 24 \\
\hline I6 & 3o. vi. & $2 \cdot 9$ & 25 & 555 & 22 & Isochrysis & & I6 \\
\hline I6 & 3o. vi. & $2 \cdot 9$ & 25 & 555 & 22 & Nitzschia & & 22 \\
\hline I6 & 30. vi. & 2.9 & 25 & 555 & 22 & Nitzschia & & 23 \\
\hline I6 & I. vii. & $2 \cdot 9$ & 25 & 555 & 22 & Nitzschia & & $5 \mathrm{I}$ \\
\hline I6 & 3. vii. & $2 \cdot 9$ & 25 & 555 & 22 & Nitzschia & & 37 \\
\hline I6 & 3. vii. & 2.9 & 25 & 555 & 22 & Nitzschia & & 47 \\
\hline I6 & 5. vii. & $2 \cdot 9$ & 25 & 555 & 22 & Nitzschia & & 37 \\
\hline II & I9. vi. & $3 \cdot 2$ & 24 & 657 & 27 & Flagellate ' $\mathrm{J}$ & & 23 \\
\hline II & I9. vi. & $3 \cdot 2$ & 24 & 657 & 27 & Flagellate ' J & & 44 \\
\hline II & I9. vi. & $3 \cdot 2$ & 24 & 657 & 27 & Flagellate ' $\mathrm{J}$ & & 45 \\
\hline \multirow[t]{2}{*}{ II } & I9. vi. & $3 \cdot 2$ & 24 & 657 & 27 & Isochrysis & & 48 \\
\hline & & & & & & \multicolumn{2}{|c|}{ Average } & 34 \\
\hline
\end{tabular}

the feeding rate (=water transport) from experiments with flagellates and Nitzschia. All experiments performed are included in it, except for those in which the mussels were not fully open and active during the experimental period. The feeding rates are shown to be comparatively larger in the smaller animals than in the bigger ones. Mytilus containing about $2 \mathrm{mg}$. $\mathrm{NH}_{2}-\mathrm{N}$ per animal filtered about $80 \mathrm{ml}$. water per hr. per mg. $\mathrm{NH}_{2}-\mathrm{N}$, whereas the value was about $30-40 \mathrm{ml}$. for animals containing about $20-30 \mathrm{mg}$. $\mathrm{NH}_{2}-\mathrm{N}$. 
In order to compute the diurnal feeding rate from these values it is necessary to know the ratio between rest and activity in the course of $24 \mathrm{hr}$. Loosanoff (I942) found that, within a wide range of temperature, Mytilus edulis is most probably almost constantly active. Between $5^{\circ}$ and $18^{\circ} \mathrm{C}$. the valves were open throughout $97-99 \%$ of the time, and food was always found in the stomach. It therefore seems justified to consider Mytilus feeding almost permanently when undisturbed. This behaviour may apply generally to plankton-feeding lamellibranchs (Loosanoff, I939; Loosanoff \& Nomeiko, I946).

MacGinitie (I94I) states that lamellibranchs normally ingest food only when they are forming the sheet of mucus on the gills. If the mucus layer is not being formed particles collected on the gills and transported by the ciliary mechanisms to the labial palps will be rejected there without entering the mouth. These statements are in disagreement with the observations made in the present investigations. In the graphite experiments, the mussels frequently could not have secreted a sheet of mucus, as they were unable to retain the smaller graphite particles. Nevertheless, they were very often found to be ingesting all the graphite which had been retained by the gills. Formation of pseudo-faeces did not necessarily occur, but, c. 30-60 min. after the addition of the graphite suspension, large amounts of real faeces were rejected through the exhalant siphon. Several examples may also be found in the literature describing ingestion of food without formation of the 'feeding mucus'. Loosanoff \& Engle (1947), for example, observed formation of large quantities of true faeces in Ostrea virginica fed on suspensions of Chlorella which were only partly retained by the gills. When feeding proceeds by means of the mucus sheet on the surface of the gills, no selection according to particle size is possible of particles imbedded in the mucus. On the other hand, we know, for instance through the very accurate and comprehensive work of Atkins (1936-38), that the gill surface possesses a very elaborate pattern of cilia which are able to sort and transport particles according to size for the purpose of either rejection or ingestion. It is difficult to believe that this complicated system of cilia should have nothing whatsoever to do with the normal feeding mechanisms of the lamellibranchs. Therefore it may be necessary to include in the normal feeding behaviour of lamellibranchs feeding ad modum MacGinitie as well as feeding by means of the filtering and sorting mechanisms provided by the cilia of the gills.

\section{SUMMARY}

The feeding rate of small specimens of Mytilus edulis (L.) has been determined in suspensions of colloidal graphite ('Prodag', grade 'C', and 'Aquadag', grade ' $\mathrm{S}$ '), of flagellates, and of Nitzschia closterium. The feeding rate was measured as the volume of water cleared from particles per unit time. In graphite suspensions, with particle size of about $4-5 \mu$, as a rule only a small 
percentage of the particles was retained by the gills, whereas flagellates of about the same size were normally nearly all retained. This difference in behaviour of the animals when kept in suspensions of graphite and flagellates, respectively, is discussed in the light of MacGinitie's observations. This author found that lamellibranchs, when feeding, secrete a continuous layer of mucus on the gills which are then able to retain even very small particles suspended in the water. When the animals are disturbed, or dislike the 'food', the formation of 'feeding mucus' is interrupted and small particles may pass and escape between the gill filaments. Therefore, it can be assumed that the mussels, when transferred to graphite suspensions, will stop forming the mucus sheet, with the result that only a small fraction of the $4-5 \mu$ graphite particles are retained by the gills. On the other hand, the layer of mucus is secreted in suspensions of flagellates, which consequently are retained in bulk by the gills. Complete retention was normally also observed in suspensions of Nitzschia. The feeding rate in suspensions of flagellates and Nitzschia was found to be $c .80 \mathrm{ml}$. per hr. per mg. $\mathrm{NH}_{2}-\mathrm{N}$ in mussels containing about $2 \mathrm{mg}$. $\mathrm{NH}_{2}-\mathrm{N}$ per animal, and about $30-40 \mathrm{ml}$. in mussels containing about $20 \mathrm{mg} . \mathrm{NH}_{2}-\mathrm{N}$.

\section{REFERENCES}

Atkins, D., 1936-38. On the ciliary mechanisms and interrelationships of lamellibranchs. I-VII. Quart. F. Micr. Sci., Vol. 79, pp. I81-308, 339-74, 375-422, 423-45; Vol. 80, pp. 32I-30, 33I-44, 345-436.

GALTSOFF, P. S., I928. Experimental study of the function of the oyster gills and its bearing on the problems of oyster culture and sanitary control of the oyster industry. Bull. Bur. Fish., Vol. 44, pp. I-39.

JøRGENSEN, C. BARKER, I943. On the water transport through the gills of bivalves. Acta Physiol. Scand., Vol. 5, pp. 297-304.

Loosanoff, V. L., I939. Effect of temperature upon shell movements of clams, Venus mercenaria (L.). Biol. Bull. Woods Hole, Vol. 76, pp. I7I-82.

- I942. Shell movements of the edible mussel, Mytilus edulis (L.), in relation to temperature. Ecology, Vol. 23, pp. 23I-4.

Loosanoff, V. L. \& Engle, J. B., I947. Effect of different concentrations of microorganisms on the feeding of oysters (O. virginica). U.S. Fish and Wildlife Serv. Bull., Vol. 5I, pp. 3I-57.

LoosanofF, V. L. \& NomeIko, C. A., I946. Feeding of oysters in relation to tidal stages and to periods of light and darkness. Biol. Bull. Woods Hole, Vol. 90, pp. 244-64.

MacGinitie, G. E., I94I. On the method of feeding of four pelecypods. Biol. Bull. Woods Hole, Vol. 80, pp. 18-25.

Parke, M., I949. Studies on marine flagellates. Fourn. Mar. Biol. Assoc., Vol. 28, pp. $255-85$.

PARNAS, J. K., I938. Ueber die Ausführung der Stickstoffbestimmung nach Kjeldahl in der Modifikation von Parnas und Wagner. Zeits. Analyt. Chem., Bd. II4, pp. $26 \mathrm{I}-75$.

ZoBell, C. E. \& LANDon, W. A., I937. The bacterial nutrition of the California mussel. Proc. Soc. Exp. Biol. Med., Vol. 36, pp. 607-9. 